\title{
Occurrence of Escherichia coli 0157:H7 in retail raw meat products in Ethiopia
}

\author{
Adem Hiko $^{1}$, Daniel Asrat ${ }^{2}$, Girma Zewde ${ }^{1}$ \\ ${ }^{1}$ Department of Veterinary Microbiology and Public Health, Faculty of Veterinary Medicine, Addis Ababa University, P.O.Box 34, \\ Debre Zeit, Ethiopia \\ ${ }^{2}$ Department of Medical Microbiology, Immunology and Parasitology, Faculty of Medicine, Addis Ababa University, P.O.Box \\ 9086, Addis Ababa, Ethiopia
}

\begin{abstract}
Background: Escherichia coli $\mathrm{O} 157: \mathrm{H} 7$ (E. coli $\mathrm{O} 157: \mathrm{H} 7)$ is now recognized as a major cause of diarrhoea, hemorrhagic colitis and hemolytic-uremic syndrome worldwide. Consumption of raw or undercooked meat of bovine origin has been the most common means of transmitting this organism.

Methodology: Over a period of 7 months (October 2006 to April 2007), a total of 738 raw meat samples were collected from bovines (n= 250), sheep $(\mathrm{n}=243)$ and goat $(\mathrm{n}=245)$ and investigated for the presence of E. coli O157: H7. Antimicrobial susceptibility testing was performed using the disk diffusion method.

Results: E. coli $\mathrm{O} 157: \mathrm{H} 7$ were isolated from 31 (4.2\%) out of 738 meat samples examined. Among meat samples examined, the highest prevalence $(8 \%)$ was recorded in beef, followed by lamb and mutton $(2.5 \%)$ and goat meat $(2 \%)$. The isolated strains were found to be susceptible $(100 \%)$ to amikacin, chloramphenicol, gentamicin, kanamycin, nalidixic acid, norfloxacin, polymyxin B and trimethoprimsulfamethoxazole. Multidrug resistance to three or more drugs was detected in 7/31 (22.6\%) strains.

Conclusions: The results of this study revealed the presence of E. coli O157:H7 in retail raw meats reaching consumers, indicating possible risks of infection to people through the consumption of raw/under-cooked meat or cross-contamination of other food products. Coordinated actions are needed to reduce or eliminate the risks posed by this organism at various stages in food chain. Multiple drug resistant isolates detected in the present study may pose a threat to humans and further limit therapeutic options.
\end{abstract}

Key Words: Escherichia coli O157:H7, prevalence, antimicrobial susceptibility, raw meat, Ethiopia

J Infect Developing Countries 2008; 2(5):389-393.

Received 18 April 2008 - Accepted 7 July 2008

Copyright (c) 2008 Hiko et al. This is an open access article distributed under the Creative Commons Attribution License, which permits unrestricted use, distribution, and reproduction in any medium, provided the original work is properly cited.

\section{Introduction}

Escherichia coli (E. coli) is a normal part of the intestinal micro-flora of many healthy animals, including humans. However, some strains can cause diseases. Verocytotoxigenic E. coli (VTEC) (also referred to as Shiga toxin-producing E. coli), including serotype $0157: \mathrm{H} 7$, are one such group, causing severe, chronic, and potentially fatal illness such as hemorrhagic colitis, hemolytic uremic syndrome, thrombotic thrombocytopenic purpura and, in severe cases, death, related to their ability to produce one or more toxins known as verotoxin or Shiga-like toxin [1]. Consumption of raw or undercooked foods of bovine origin has been the most common means of transmitting VTEC organisms in sporadic cases and in outbreaks of VTEC infection [2].

Nevertheless, a variety of other foods have also been implicated in causing outbreaks [3,4]. Antibiotic use in VTEC infections is controversial because of the potential to increase production and secretion of Shiga toxins [5]. However, increase in antibiotic resistance has been noted over the last 20 years [6-8]. Outbreaks of $E$. coli $\mathrm{O} 157$ have been reported in different parts of the world [9-11].

However, little is known about the prevalence of this serogroup in Ethiopia, either in humans or in the animal population or in foods [12]. The present study was conducted to address the lack of information pertaining to the prevalence and antibiotic susceptibility profiles of E. coli O157:H7 in raw meat obtained from food animals in Ethiopia where raw meat from these sources is widely consumed. 


\section{Materials and Methods}

Ethical considerations

The research project was approved by the Academic Commission of the Faculty of Veterinary Medicine, Addis Ababa University, Addis Ababa, Ethiopia.

\section{Study area}

Over a period of 7 months (October 2006 to April 2007), a prevalence survey of E. coli O157:H7 was conducted on meat samples obtained from legally registered butcher shops, municipal abattoirs, and selected export abattoirs at Debre-Zeit and Modjo towns, which are allocated at 45 and $70 \mathrm{~km}$, respectively from the Addis Ababa, the capital city of the Federal Republic of Ethiopia.

\section{Sample collection, handling and transport}

A total of 738 raw meat samples were collected from municipal abattoirs $(\mathrm{n}=177)$, export abattoirs $(n=433)$ and butcher shops $(n=128$ (Table 1). The meat samples were from bovines $(n=250)$, sheep $(n=243)$ and goat $(\mathrm{n}=245)$. Of the 738 meat samples, $406(55 \%)$ and $333(45 \%)$ were collected from Debre Zeit and Modjo Towns, respectively. All the meat samples were readyto-eat fresh and collected aseptically, placed into sterile containers, and transported to the Microbiology Laboratory of the Faculty of Veterinary Medicine, Addis Ababa University, located at Debre Zeit. Samples were transported in ice boxes and analyzed within 6 to 12 hours.

Table 1. Meat samples investigated for E. coli $\mathrm{O} 157: \mathrm{H} 7$ obtained from abattoirs and butcher shops, Debre Zeit and Modjo towns, Ethiopia.

\begin{tabular}{|c|c|c|c|}
\hline \multirow{3}{*}{ Raw meat type } & \multicolumn{3}{|c|}{ Meat source } \\
\hline & \multicolumn{2}{|l|}{ Abattoirs } & \multirow{2}{*}{$\begin{array}{l}\text { Butcher } \\
\text { shops } \\
\text { no. }(\%)\end{array}$} \\
\hline & $\begin{array}{l}\text { Export } \\
\text { no. }(\%)\end{array}$ & $\begin{array}{l}\text { Municipality } \\
\text { no. }(\%)\end{array}$ & \\
\hline $\operatorname{Beef}(n=250)$ & $40(16.0)$ & $124(49.6)$ & $86(34.4)$ \\
\hline Mutton $(\mathrm{and} /$ or lamb) $(\mathrm{n}=243)$ & $188(77.4)$ & $35(14.4)$ & $20(8.2)$ \\
\hline Goat's meat $(n=245)$ & $205(84.0)$ & $18(7.0)$ & $22(9.0)$ \\
\hline Total $(\mathrm{n}=738)$ & $433(59.0)$ & $177(24.0)$ & $128(17.0)$ \\
\hline
\end{tabular}

\section{Sample preparation and selective enrichment}

Enrichment cultures for each meat sample were conducted by combining $25 \mathrm{~g}$ of each sample with 225 $\mathrm{ml}$ of tryptone soya broth (Oxoid Ltd, Basingstoke, UK) supplemented with $20 \mathrm{mg} / \mathrm{l}$ novobiocin (Sigma, Germany) in a stomacher bag, homogenizing for at least 2 minutes in a stomacher (Lab Blender 400, Seward Medical, London, UK) and incubating at $37^{\circ} \mathrm{C}$ for 16 to $18 \mathrm{~h}$.
Culture and isolation of E. coli $\mathrm{O} 157: \mathrm{H} 7$

All enriched meat samples were subsequently subcultured onto eosin methylene blue (EMB) agar (Difco Laboratories, USA) for primary screening of $E$. coli and incubated aerobically at $37^{\circ} \mathrm{C}$ for 24 hours. Suspected colonies of E. coli (greenish metallic sheen appearance with dark purple centers) were biochemically identified using API 20E gallery (API20E/20100, bioMerieux, Marcy l'Etoile, France) and subsequently they were further screened for $E$. coli O157:H7. In brief, 2-3 biochemically confirmed E. coli were subcultured on Sorbitol MacConkey Agar (Oxoid), supplemented with $0.05 \mathrm{mg} / \mathrm{l}$ cefixime and 2.5 $\mathrm{mg} / \mathrm{l}$ tellurite (Oxoid) (SMAC-CT) and incubated at $37^{\circ} \mathrm{C}$ for 18 to 24 hours. Following the end of the incubation period, the SMAC-CT agar plates were examined for the presence of non-sorbitol fermenter colonies and subsequently they were further processed for serological identification. The type strain $E$. coli O157:H7 (ATCC 43895) was placed into $10 \mathrm{ml}$ of Brain Heart Infusion broth (BHI) (Oxoid) and incubated for 24 hours at $37^{\circ} \mathrm{C}$. The resulting culture was streaked out on SMAC-CT agar and incubated for 24 hours at $37^{\circ} \mathrm{C}$. This was used as a positive control.

\section{Serological identification}

All non-sorbitol fermenting colonies from the SMAC-CT agar were subjected to slide agglutination with the E. coli $\mathrm{O} 157$ Latex test kit (Oxoid). The latex beads were coated with antibodies which bind to any $\mathrm{O} 157$ or $\mathrm{H} 7$ antigens on the test organisms, forming a visible antigen antibody precipitate [13]. Colonies giving a precipitation reaction were confirmed as $E$. coli O157:H7 positive.

\section{Antimicrobial susceptibility testing}

The isolated E. coli $\mathrm{O} 157: \mathrm{H} 7$ strains were tested for antibiotic resistance to thirteen antimicrobial agents obtained from Oxoid [amikacin (AK) $(30 \mu \mathrm{g})$, ampicillin (AMP) $(10 \mu \mathrm{g})$, cephalothin (KF), $(30 \mu \mathrm{g})$, chloramphenicol (C) $(30 \mu \mathrm{g})$, gentamicin $(\mathrm{CN})(10 \mu \mathrm{g})$, kanamycin $(\mathrm{K})(30 \mu \mathrm{g})$, nalidixic acid $(30 \mu \mathrm{g})$ (NA), norfloxacin (NOR) $(10 \mu \mathrm{g})$, polymyxin B (PB) $(300$ units), streptomycin (S) $(10 \mu \mathrm{g})$, trimethoprim (W) $(5 \mu \mathrm{g})$, trimethoprim-sulphamethoxazole (SXT) (25 $\mu \mathrm{g})$ and tetracycline (TE) $(30 \mu \mathrm{g})]$ using the disc diffusion method according to the criteria of the National Committee for Clinical Laboratory Standards (NCCLS) [14]. The isolates were classified as sensitive, intermediate, and resistant using the breakpoints of the NCCLS [14]. A standard reference strain of E. coli 
(ATCC 25922), sensitive to all antimicrobial drugs being tested, was used as a control strain.

\section{Statistical analysis}

EPI-INFO Version 6 soft package (CDC, Atlanta GA) was used for statistical analysis. Comparisons were made using Chi-square test with Yates' correction or Fisher exact tests. A p-value of $<0.05$ was considered indicative of a statistically significant difference.

\section{Results}

Prevalence of E. coli $0157: H 7$

Out of 738 meat samples examined, 31 (4.2\%) were found to be contaminated with $E$. coli O157:H7 (Table 2 ). Beef was found to be most frequently contaminated with $E$. coli $\mathrm{O} 157: \mathrm{H} 7$ (8\%) when compared to the other raw meat types examined $(2-2.5 \%)(\mathrm{p}<0.05)$. The rate of $E$. coli $\mathrm{O} 157: \mathrm{H} 7$ isolated from all meat sources was found to be higher from butcher shops (7.8\%) than from municipality abattoirs (6.8\%) and export abattoirs $(2.3 \%)(\mathrm{p}<0.05)$.

Table 2. Prevalence of Escherichia coli O157: H7 isolated from raw meats samples in Ethiopia.

\begin{tabular}{|c|c|c|c|c|}
\hline \multirow[b]{2}{*}{$\begin{array}{l}\text { Meat type } \\
\text { investigated }\end{array}$} & \multicolumn{4}{|c|}{ Prevalence rates $(\%)$ according to the Sources } \\
\hline & $\begin{array}{l}\text { Export } \\
\text { Abattoir }\end{array}$ & $\begin{array}{l}\text { Municipality } \\
\text { Abattoir }\end{array}$ & $\begin{array}{l}\text { Butcher } \\
\text { shops }\end{array}$ & Total \\
\hline Beef & $\begin{array}{l}2 / 40 \\
(5)^{\mathrm{a}}\end{array}$ & $\begin{array}{l}10 / 124 \\
(8.1)\end{array}$ & $\begin{array}{l}8 / 86 \\
(9.3)\end{array}$ & $\begin{array}{l}20 / 250 \\
(8)\end{array}$ \\
\hline $\begin{array}{l}\text { Mutton and/or } \\
\text { lamb }\end{array}$ & $\begin{array}{l}4 / 188 \\
(2.1)\end{array}$ & $\begin{array}{l}1 / 35 \\
(2.8)\end{array}$ & $\begin{array}{l}1 / 20 \\
(5)\end{array}$ & $\begin{array}{l}6 / 243 \\
(2.5)\end{array}$ \\
\hline Goat meat & $\begin{array}{l}3 / 205 \\
(1.5)\end{array}$ & $\begin{array}{l}1 / 18 \\
(5.5)\end{array}$ & $\begin{array}{l}1 / 22 \\
(4.5)\end{array}$ & $\begin{array}{l}5 / 245 \\
(2)\end{array}$ \\
\hline Total & $\begin{array}{l}9 / 433 \\
(2.1)\end{array}$ & $\begin{array}{l}12 / 177 \\
(6.8)\end{array}$ & $\begin{array}{l}\text { 10/128 } \\
(7.8)\end{array}$ & $\begin{array}{l}31 / 738 \\
(4.2)\end{array}$ \\
\hline
\end{tabular}

\section{Antimicrobial susceptibility patterns}

The isolated strains were susceptible (100\%) to amikacin, chloramphenicol, gentamicin, kanamycin, nalidixic acid, norfloxacin, polymyxin $\mathrm{B}$ and trimethoprim-sulfamethoxazole (Table 3). Multidrug resistance (MDR) to three or more drugs was detected in $7 / 31(22.6 \%)$ strains. Of the 7 MDR strains, 3 were resistant to three drugs (streptomycin, tetracycline and ampicillin), 2 were resistant to four drugs (streptomycin, cepahlothin, tetracycline and ampicillin), and 2 were resistant to five drugs (streptomycin, cephlaothin, tetracycline, ampicillin and trimethoprim).

\section{Discussion}

EHEC strains belonging to serogroup EHEC O157 are most frequently associated with human disease [15]. However, EHEC strains of other serotypes from human, animal, and food sources have been reported and nonsorbitol fermenting O157:H7 strains detected in this study could potentially only represent a fraction of potential EHEC contamination [15]. In the present study, beef was more frequently contaminated with $E$. coli $\mathrm{O} 157: \mathrm{H} 7$ compared to other meat samples examined (Table 2). This percentage is high in comparison with the prevalence of $0-5 \%$ reported elsewhere in the world [16-19]. However, there are reports from different parts of the world that show a high contamination rate of beef with E. coli $\mathrm{O} 157: \mathrm{H} 7$, e.g. 14.7\%-22.5\% in Peru [20], 31\% in Canada [21] and $90 \%$ in the USA [22].

Table 3. Antimicrobial susceptibility profile of Escherichia coli 0157:H7isolated from raw meat samples.

\begin{tabular}{|c|c|c|c|c|c|c|}
\hline \multirow{3}{*}{ 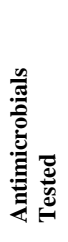 } & \multicolumn{6}{|l|}{ Source } \\
\hline & \multicolumn{3}{|c|}{ Goat meat $(n=5)$} & \multicolumn{3}{|c|}{ Mutton and/or lamb (n=6) } \\
\hline & $\begin{array}{l}S^{*} \\
\text { No. } \\
(\%)\end{array}$ & $\begin{array}{l}\mathrm{I}^{*} \\
\text { No. } \\
(\%) \\
\end{array}$ & $\begin{array}{l}\mathrm{R}^{*} \\
\text { No. } \\
(\%)\end{array}$ & $\begin{array}{l}S^{*} \\
\text { No. } \\
(\%)\end{array}$ & $\begin{array}{l}\mathrm{I}^{*} \\
\text { No. } \\
(\%) \\
\end{array}$ & $\begin{array}{l}\mathrm{R}^{*} \\
\text { No. } \\
(\%) \\
\end{array}$ \\
\hline $\mathbf{A K}$ & $5(100)$ & - & $0(0)$ & $6(100)$ & - & $0(0)$ \\
\hline AMP & $5(100)$ & - & $0(0)$ & $6(100)$ & - & $0(0)$ \\
\hline KF & $4(80)$ & - & $1(20)$ & $5(83.3)$ & - & $1(16.7)$ \\
\hline $\mathbf{C}$ & $5(100)$ & - & $0(0)$ & $6(100)$ & - & - \\
\hline CN & $5(100)$ & - & $0(0)$ & $6(100)$ & - & - \\
\hline $\mathbf{K}$ & $5(100)$ & - & $0(0)$ & $6(100)$ & - & - \\
\hline NA & $5(100)$ & - & $0(0)$ & $6(100)$ & - & - \\
\hline NOR & $5(100)$ & - & $0(0)$ & $6(100)$ & - & - \\
\hline PB & $5(100)$ & - & $0(0)$ & $6(100)$ & - & - \\
\hline $\mathbf{S}$ & $4(80)$ & - & $1(20)$ & $5(83.3)$ & - & $1(16.7)$ \\
\hline SXT & $5(100)$ & - & - & $6(100)$ & - & - \\
\hline TE & $5(100)$ & - & - & $5(83.3)$ & - & $1(16.7)$ \\
\hline $\mathbf{w}$ & $5(100)$ & - & - & $6(100)$ & - & $0(0)$ \\
\hline \multirow{3}{*}{ 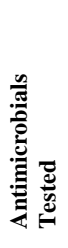 } & \multicolumn{6}{|l|}{ Source } \\
\hline & \multicolumn{3}{|c|}{ Beef $(n=20)$} & \multicolumn{3}{|c|}{ Total $(\mathbf{n}=\mathbf{3 1})$} \\
\hline & $\begin{array}{l}\mathrm{S}^{*} \\
\text { No. } \\
(\%) \\
\end{array}$ & $\begin{array}{l}I^{*} \\
\text { No. } \\
(\%)\end{array}$ & $\begin{array}{l}\mathrm{R}^{*} \\
\text { No. } \\
(\%)\end{array}$ & $\begin{array}{l}S^{*} \\
\text { No. } \\
(\%) \\
\end{array}$ & $\begin{array}{l}I^{*} \\
\text { No. } \\
(\%) \\
\end{array}$ & $\begin{array}{l}\mathrm{R}^{*} \\
\text { No. } \\
(\%) \\
\end{array}$ \\
\hline AK & $20(100)$ & - & - & $31(100)$ & - & $0(0)$ \\
\hline AMP & $18(90)$ & - & $2(10)$ & $29(93.5)$ & - & $2(6.5)$ \\
\hline KF & $15(75)$ & - & $5(25)$ & $24(77.4)$ & - & $7(22.6)$ \\
\hline C & $20(100)$ & - & - & $31(100)$ & - & - \\
\hline $\mathrm{CN}$ & $20(100)$ & - & - & $31(100)$ & - & - \\
\hline $\mathbf{K}$ & $20(100)$ & - & - & $31(100)$ & - & - \\
\hline NA & $20(100)$ & - & - & $31(100)$ & - & - \\
\hline NOR & $20(100)$ & - & - & $31(100)$ & - & - \\
\hline PB & $20(100)$ & - & - & $31(100)$ & - & - \\
\hline $\mathbf{S}$ & $10(50)$ & $2(10)$ & $8(40)$ & 19 (61.3) & $2(6.5)$ & $10(32.2)$ \\
\hline SXT & $20(100)$ & - & - & $31(100)$ & - & - \\
\hline TE & $14(70)$ & - & $6(30)$ & $24(77.4)$ & - & $7(22.6)$ \\
\hline $\mathbf{w}$ & $17(85)$ & - & $3(15)$ & $28(90.3)$ & - & $3(9.7)$ \\
\hline
\end{tabular}


E. coli $\mathrm{O} 157: \mathrm{H} 7$ was recovered at lower prevalence in meat samples obtained from sheep $(2.5 \%)$ and goat (2\%) than beef in the present study. This finding is in close agreement with the reported prevalence of $2.9 \%$ in the United Kingdom [17] and 2\% in Canada [21]. This might be due to low fecal prevalence of $E$ coli $\mathrm{O} 157: \mathrm{H} 7$ in these animals, which results in relatively low risk of contamination. The overall variations in the prevalence of E. coli O157:H7 may be a result of different sampling techniques employed and laboratory methodologies used, and may also be due to the reason that the studies were conducted in different countries at different times. Since virulence gene detection was not performed, the data derived in this study should only be considered presumptive; however, the high prevalence of O157:H7 strains identified with the limited available methodology gives cause for concern.

The E. coli $\mathrm{O} 157: \mathrm{H} 7$ strains isolated in this study were all found susceptible to most antibiotics tested. Similar findings have been reported by other researchers [16,23]. However, resistant strains do exist mainly to ampicillin, tetracycline, streptomycin, cephalothin and sulphamethoxazole [6,18,23,24] and were detected in the present study. Multidrug resistance was found in $22.6 \%$ of the strains. Similar findings have been observed in other studies [6,7].

Although other enterohemorrhagic E. coli (EHEC) serotypes and the virulence factors of E. coli $\mathrm{O} 157: \mathrm{H} 7$ were not investigated because of laboratory facility limitations, this study revealed that various retail raw meats products from foods of animal origin are often contaminated with E. coli $\mathrm{O} 157: \mathrm{H} 7$, suggesting possible risks of infection to people through consumption of raw/undercooked meat or cross-contamination of other foods.

The available evidence also shows that meats from foods of animal origin serve as potential vehicles for transmitting $E$. coli $\mathrm{O} 157: \mathrm{H} 7$; interruption of transmission to humans should be given a high priority. The importance of proper handling and cooking of foods of animal origin are probably as important in preventing E. coli O157:H7 infections as they are in preventing Salmonella and Campylobacter infections.

Coordinated actions are needed to reduce or eliminate the risks posed by this organism at various stages in the food chain. These include Good Agricultural practice (GAP), Good Manufacturing practice (GMP), and Hazard Analysis of Critical Control Points (HACCP) at every stage of the meat supply chain, from the farm through to the abattoir, to the retailer, and to those involved with the handling and processing of such raw meat products in the home environment. Antibiotic resistance in most strains in this study is low. However, MDR organisms may become a public health risk should they enter the food chain.

\section{Acknowledgements}

We would like to thank the owners of abattoirs and butcher shops at Debre-Zeit and Modjo towns for co-operation in all aspects of our study. We would like also to extend our heartfelt thanks to Dr. Rosemarie Blatz from Leipzig University, Germany, for providing us SMAC-CT agar.

\section{References}

1. Tarr PI (1995) Escherichia coli O157:H7: clinical, diagnostic and epidemiological aspects of human infection. Clin Infect Dis 20: $1-10$.

2. Uhitil S, Jaksic S, Petrak T, Botka-Petrak K (2004) Presence of Escherichia coli $\mathrm{O} 157: \mathrm{H} 7$ in ground beef and ground baby beef meat. J Food Prot 64: 862-864.

3. Bielaszewska M, Janda J, Blahova K, Minarıkova H, J1kova E, Karmali MA, Laubova J, Sikulova J, Preston MA, Khakhria R, Karch H, Klazarova H, Nyc O (1997) Human Escherichia coli O157:H7 infection associated with the consumption of unpasteurized goat's milk. Epidemiol Infect 119: 299-305.

4. McDonnell RJ, Rampling A, Crook S, Cockcroft PM, Willshaw GA, Cheasty T, Stuart J (1997) An outbreak of Vero cytotoxin producing Escherichia coli $\mathrm{O} 157$ infection associated with takeaway sandwiches. CDR Wkly 7: R201-R205.

5. Zhang, X, McDaniel AD, Wolf LE, Keusch GT, Waldor MK, Acheson DW (2000) Quinolone antibiotics induce Shiga toxinencoding bacteriophages, toxin production, and death in mice. $\mathrm{J}$ Infect Dis 181: 664-670.

6. Meng J, Zhao S, Doyle MP, Joseph SW (1998) Antibiotic resistance of Escherichia coli O157:H7 and O157: NM isolated from animals, food, and humans. J Food Prot 61: 1511-1514.

7. Mora A, Blanco JE, Blanco M, Alonso MP, Dhabi G, Echeita A, González EA, Bernárdez MI, Blanco J (2005) Antimicrobial resistance of Shiga toxin (verotoxin)-producing Escherichia coli $\mathrm{O} 157: \mathrm{H} 7$ and non-O157 strains isolated from humans, cattle, sheep and food in Spain. Res Microbiol 156: 793-806.

8. Walsh C, Duffy G, O'Mahony R, Fanning S, Blair IS, McDowell DA (2006) Antimicrobial resistance in Irish isolates of verocytotoxigenic Escherichia coli (E. coli)-VTEC. Int J Food Microbiol 109:173-8.

9. Riley LW, Remis RS, Helgerson SD, McGee HB, Wells JG, Davis BR, Hebert RJ, Olcott ES, Johnson LM, Hargrett NT, Blake PA, Cohen ML (1983) Hemorrhagic colitis associated with a rare Escherichia coli serotype. N Eng J Med 308: 681685.

10. Tamura K, Sakazaki R, Murase M, Kosako Y (1996) Serotyping and categorization of Escherichia coli strains isolated between 1958 and 1992 from diarrhoeal diseases in Asia. J Med Microbiol 45: 353- 358.

11. Raji MA, Minga U, Machangu R (2006) Current epidemiological status of enterohaemorrhagic Escherichia coli O157:H7 in Africa. Chin Med J (English) 119: 217-222.

12. Tsegaye M, Ashenafi M. (2005) Fate of Escherichia coli O157:H7 during the processing and storage of Ergo and Ayib, traditional Ethiopian dairy products. Int J Food Microbiol 103:11-21. 
13. De Boer E, Heuvelink AE (2000) Methods for the detection and isolation of Shiga toxin-producing E. coli. J Appl Microbiol Symp Suppl. 88: 1335-1435.

14. National Committee for Clinical Laboratory Standards (2000) Performance standards for antimicrobial disk susceptibility tests. In: Approved Standard M2-A7, seventh ed. National Committee for Clinical Laboratory Standards, Wayne, PA.

15. Chapman PA (1994) Isolation, identification and typing of verotoxin producing Escherichia coli O157. PHLS Microbiol Digest 11: 13-27.

16. Dontorou C, Papadopoulou C, Filioussis G, Economou V, Apostolou I, Zakkas G, Salamoura A, Kansouzidou A, Levidiotou S (2003) Isolation of Escherichia coli O157:H7 from foods in Greece. Int J Food Microbiol 82: 273-279.

17. Chapman PA, Siddons CA, Cerdan Malo AT, Harkin MA (2000) A one year study of Escherichia coli O157 in raw beef and lamb products. Epidemiol Infect 124: 207-213.

18. Magwira CA, Gashe BA, Collison EK (2005) Prevalence and antibiotic resistance profiles of Escherichia coli $\mathrm{O} 157: \mathrm{H} 7$ in beef products from retail outlets in Gaborone, Botswana. J Food Prot 68: 403-406.

19. Mayrhofer S, Paulsen P, Smulders FJM, Hilbert H (2004) Antimicrobial resistance profile of five major food-borne pathogens isolated from beef, pork and poultry. Int J Food Microbiol 97: 23-29.

20. Mora A, León SL, Blanco M, Blanco JE, Lópe, C, Dahbi G, Echeita A, González EA, Blanco J (2007) Phage types, virulence genes and PFGE profiles of Shiga toxin-producing Escherichia coli 0157:H7 isolated from raw beef, soft cheese and vegetables in Lima (Peru). Int J Food Microbiol 114: 204210.

21. Doyle MP, Schoeni JL (1987) Isolation of Escherichia coli O157:H7 from retail fresh meats and poultry. Appl Environ Microbiolol 53:2394- 2396.

22. Hoyle B (2000) Renewed concerns over Escherichia coli O157:H7 in ground beef. ASM News 66:331-332.

23. Reyes MS, Durán CT, Prado VJ (2004) Antimicrobial susceptibility of shiga toxin producing Escherichia coli (STEC) strains isolated from human infections and food. Rev Med Chil 132: 1211-1216.

24. Schroeder CM, Zhao C, Deb Roy C, Torcolini J, Zhao S, White DG, Wagner DD, McDermott PF, Walker RD, Meng J (2002) Antimicrobial resistance of Escherichia coli $\mathrm{O} 157$ isolated from humans, cattle, swine, and food. Appl Environ Microbiol 68: $576-581$
Corresponding Author: Daniel Asrat, Department of Medical Microbiology, Immunology and Parasitology, Faculty of Medicine, Addis Ababa University, P.O.Box 9086, Addis Ababa, Ethiopia

E-mail: asratdaniel@ethionet.et

Conflict of interest: No conflict of interest is declared. 